\title{
ETIKA DAN MANAJEMEN BISNIS ISLAM (STUDI KASUS DI WAROENG STEAK AND SHAKE CABANG SM RAJA MEDAN)
}

\author{
Rizka Ar Rahmah \\ e-mail: rizkafe@yahoo.co.id
}

\begin{abstract}
Abstrak
Penelitian ini bertujuan untuk mengetahui konsep bisnis Islam dan konsep manajemen bisnis Islam yang dilaksanakan di Waroeng Steak and Shake Cabang SM Raja Medan. Waroeng Steak and Shake ini adalah salah satu bisnis kuliner yang melandasi setiap kegiatan bisnisnya sesuai dengan aturan Al-quran dan Sunnah. Penelitian ini menggunakan pendekatan kualitatif. Untuk teknik validasi data dilakukan dengan cara menggali informasi dari beberapa informan yang berkaitan langsung dengan bisnis tersebut. Selain itu peneliti juga melakukan observasi langsung di lokasi. Hasil dari analisis penelitian menunjukkan bahwa konsep etika bisnis Islam di Waroeng Steak sudah baik untuk konsep Shiddiq yakni menjamin bahan baik dan halal serta kejujuran dalam bertransaksi. Untuk konsep Tabligh dalam hal penyampaian dakwah melalui bisnis juga sudah baik. Namun ada kelemahan dari segi Amanah yaitu dalam hal pelayanan. Untuk konsep Fathanah yaitu kecerdasan spiritual juga perlu ditingkatkan kembali. Konsep manajemen bisnis Islam sudah baik dalam hal (1). perencanaan yang menyangkut lima hal yaitu: Visi dan Misi, produksi, distribusi, perekrutan karyawan dan jenjang karir (2). pengorganisasian dalam hal pembagian tugas sudah masuk dalam kategori baik. Untuk (3) pengawasan juga sudah dalam kategori baik yaitu dengan rutin mengadakan briefieng setiap pagi. (4) pelaksanaan juga sudah baik yaitu dalam bentuk apresiasi dan spiritual company.
\end{abstract}

Kata Kunci: Etika, Manajemen, Bisnis Islam

\section{PENDAHULUAN}

Bisnis merupakan sesuatu yang sangat penting dalam kehidupan manusia. Tidak heran jika Islam yang bersumber pada Alquran dan Sunnah memberi tuntunan dalam bidang usaha. Bisnis selama ini, dikesankan sebagai usaha mencari keuntungan sebanyak-banyaknya, bahkan harus ditempuh dengan cara kotor dan tidak etis. Islam tidak membiarkan begitu saja seseorang bekerja sesuka hati untuk mencapai keinginannya dengan menghalalkan segala cara seperti melakukan penipuan, kecurangan, sumpah palsu, riba, menyuap dan perbuatan batil lainnya. Tetapi dalam Islam diberikan suatu batasan atau garis pemisah antara yang boleh dan yang tidak boleh, yang benar dan salah serta yang halal dan yang haram. Allah swt telah menetapkan batas-batas tertentu terhadap perilaku manusia sehingga menguntungkan satu individu tanpa men- 
gorbankan hak-hak individu lainnya. Batasan atau garis pemisah inilah yang dikenal dengan istilah etika.

Etika bisnis Islam bertujuan mengajarkan manusia untuk menjalin kerjasama, tolong menolong, dan menjauhkan diri dari sikap dengki dan dendam serta hal-hal yang tidak sesuai dengan syariah. Etika bisnis dalam Islam juga berfungsi sebagai controlling (pengatur) terhadap aktifitas ekonomi pedagang, karena secara filosofi etika mendasarkan diri pada nalar ilmu dan agama untuk menilai. Landasan penilaian ini dalam praktek kehidupan di masyarakat sering kita temukan bahwa secara agama terdapat nilai mengenai hal-hal baik, buruk atau jahat, seperti pihak yang mendzalimi dan terdzalimi (Mulich: 2004:29). Dengan begitu maka setiap individu yang melakukan kegiatan ekonomi baik seorang pebisnis atau yang menjalankan aktivitas ekonomi maka harus memiliki pengetahuan akan etika bisnis Islam agar terhindar dari tindakan bisnis yang dilarang oleh Allah SWT.

Untuk menjalankan kegiatan bisnisnya, selain memiliki etika seorang entrepreneur harus mampu mengelola dan mengkombinasikan berbagai macam sumber daya yang dimiliki, sehingga mampu berproduksi secara optimal. Mengelola dan mengkombinasikan berbagai macam sumber daya itu disebut manajemen.

Jika didefinisikan manajemen adalah suatu rangkaian aktifitas (termasuk perencanaan, pengambilan keputusan, pengorganisasian, kepemimpinan, dan pengendalian) yang diarahkan pada sumber daya organisasi (manusia, financial, fisik dan informasi) dengan maksud untuk mencapai tujuan organisasi secara efektif dan efisien (Griffin, 2004:20).

Etika dan manajemen bisnis Islam telah dilaksanakan pada berbagai bisnis di Indonesia, salah satunya adalah pada bisnis kuliner. Pada saat ini, bisnis kuliner telah menjadi salah satu bisnis yang sangat banyak diminati. Bisnis ini tergolong sangat menguntungkan apabila banyak yang suka dengan jenis makanan serta rasa yang ditawarkan. Tidak mengherankan lagi apabila kita berjalan-jalan dan melihat sebuah tempat makan dipadati pengunjung, bahkan ada beberapa yang rela mengantri untuk dapat menikmati hidangan yang disajikan.

Salah satu bisnis kuliner yang sudah terkenal saat ini adalah Waroeng Steak and Shake. Waroeng Steak and Shake adalah warung yang menjual makanan berupa aneka menu steak dan minuman. Awal mula berdirinya Waroeng Steak and Shake ini pada tahun 2000. Kini gerai Waroeng Steak and Shake sudah bertambah menjadi 63 gerai dengan memperkerjakan 1.000 karyawan. Dimana pada Waroeng Steak and Shake ini menerapkan spiritual company yang terdiri dari dakwah dan pendidikan Is- 
Rizka Ar Rahmah: Etika dan Manajemen

lam. Untuk dakwah dilakukan melalui olahraga, kegiatan sosial, infaq karyawan dan seni budaya. Sedangkan untuk pendidikan Islamnya yakni pengadaan tausyiah rutin di outlet-outlet dan kantor, buletin bulanan dan belajar membaca Alquran.

\section{Kajian Pustaka}

\section{Kajian Tentang Etika Bisnis Islam \\ a. Pengertian Etika Bisnis Islam}

Etika berasal dari bahasa yunani ethos. Secara etimologis, etika bermakna watak, susila, adat. Sedangkan secara terminologis, dapat diartikan: (1) menjelaskan arti baik atau buruk, (2) menerangkan apa yang seharusnya dilakukan, (3) menunjukkan tujuan dan jalan yang harus dituju, (4) menunjukkan apa yang harus dilakukan. Dengan demikian, dapat disimpulkan bahwa etika adalah seperangkat nilai yang merupakan hasil gagasan manusia mengenai tata aturan yang berkaitan dengan prilaku manusia dan menjadi layak, wajar, sehingga bias diterima suatu komunitas pada ruang dan waktu tertentu (Tim Penyusun MKD IAIN Sunan Ampel Surabaya, 2011:59-60).

Ada beberapa persamaan antara akhlak, moral, dan etika adalah: Pertama, akhlak, etika dan moral mengacu pada ajaran atau gambaran tentang perbuatan, tingkah laku, sifat, dan perangai yang baik. Kedua, akhlak, moral dan etika merupakan prinsip atau aturan hidup manusia untuk mengukur martabat dan harkat kemanusiaannya. Ketiga, akhlak, moral dan etika seseorang atau sekelompok orang tidak semata-mata merupakan faktor keturunan yang bersifat tetap, statis, dan konstan, tetapi merupakan potensi positif yang dimiliki setiap orang. Perbedaan antara akhlak, moral dan etika adalah: akhlak tolak ukurnya dengan menggunakan Al-Qur'an dan Sunnah. Etika tolak ukurnya adalah dengan menggunakan pikiran atau akal. Sedangkan moral tolak ukurnya dengan menggunakan norma hidup yang ada dalam masyarakat (Anwar, 2010:20).

Etika bisnis dapat berarti pemikiran atau refleksi tentang moralitas dalam ekonomi dan bisnis. Moralitas disini berarti aspek baik atau buruk, terpuji atau tercela, benar atau salah dari prilaku manusia. Kemudian dalam kajian etika bisnis islam susunan adjective diatas ditambah dengan halal dan haram.

Etika bisnis dalam Islam adalah sejumlah perilaku etika bisnis (akhlaq alislamiyah) yang dibungkus dengan nilai-nilai syariah yang mengedepankan halal dan haram. Jadi perilaku yang etis itu ialah perilaku yang mengikuti perintah Allah dan menjauhi larangnya. Dalam islam etika bisnis ini sudah banyak dibahas dalam berbagai literatur dan sumber utamanya adalah Alquran dan sunnaturrasul. Pelaku-pelaku 
bisnis diharapkan bertindak secara etis dalam berbagai aktivitasnya. Kepercayaan, keadilan dan kejujuran adalah elemen pokok dalam mencapai suksesnya suatu bisnis dikemudian hari.

\section{b. Prinsip-Prinsip Etika Bisnis Islam}

Rasulullah SAW memiliki sifat - sifat ke Rasul-an yang menjadi dasar etika bisnis ala Rasulullah yaitu Shidiq, Amanah, Tabligh dan Fathanah. Kejujuran (as-sidiq) dan kepercayaan (al-amin) menjadi prinsip utama Rasulullah Saw dalam berbisnis, selain itu beliau juga terhitung sebagai orang yang cerdas (fatanah) dengan pemikiran yang visioner, kreatif dan inovatif, serta pintar mempromosikan diri dan bisnisnya (tabligh) atau dalam istilah ekonomi dikenal dengan marketing, semua itu menyatu dalam diri Rasulullah SAW.

\section{Siddiq}

Siddiq artinya benar. Bukan hanya perkataannya yang benar, tapi juga perbuatannya juga benar. Sejalan dengan ucapannya. (QS. An-Najm : 4)<smiles>[Ge]=[As][As]=[As]</smiles>

"Ucapannya itu tiada lain hanyalah wahyu yang diwahyukan (kepadanya)"

Seorang pemimpin senantiasa berprilaku benar dan jujur dalam sepanjang kepemimpinannya, dan seorang pemasar haruslah sifat shiddiq haruslah menjiwai setiap prilakunya dalam melakukan pemasaran, dalam berhubungan dengan pelanggan, dalam bertransaksi dengan nasabah, dan dalam menjalin kerjasama dan perjanjian dengan mitra bisnisnya.

\section{Amanah}

Amanah artinya benar-benar bisa dipercaya. Jika satu urusan diserahkan kepadanya, niscaya orang percaya bahwa urusan itu akan dilaksanakan dengan sebaik-baiknya. Oleh karena itulah Rasulullah Saw dijuluki oleh penduduk Mekkah dengan gelar "Al Amin" yang artinya terpercaya jauh sebelum beliau diangkat jadi Nabi. Apa pun yang beliau ucapkan, penduduk Mekkah mempercayainya karena beliau bukanlah orang yang pembohong. Sebagaimana telah diterangkan dalam ayat berikut ini: (QS. Al-A'raaf : 68)

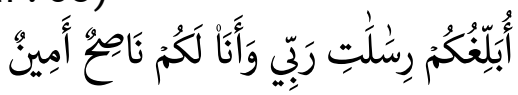

"Aku menyampaikan amanat-amanat Tuhanku kepadamu dan aku hanyalah pemberi nasehat yang terpercaya bagimu".

Dapat dipercaya, bertanggung jawab, juga bermakna keinginan untuk memenuhi sesuatu sesui dengan ketentuan. Menyelaraskan nilai yang terkait 
dengan kejujuran dan melengkapinya.

3. Tabligh

Tabligh artinya menyampaikan. Segala firman Allah yang ditujukan oleh manusia, disampaikan oleh Nabi.Tidak ada yang disembunyikan meski itu menyinggung Nabi.

"Supaya Dia mengetahui, bahwa Sesungguhnya Rasul-rasul itu telah menyampaikan risalah-risalah Tuhannya, sedang (sebenarnya) ilmu-Nya meliputi apa yang ada pada mereka, dan Dia menghitung segala sesuatu satu persatu". (QS. Al Jin : 28)

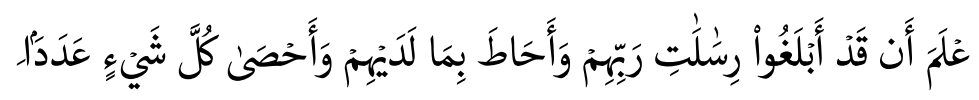

"Supaya Dia mengetahui, bahwa sesungguhnya rasul-rasul itu telah menyampaikan risalah-risalah Tuhannya, sedang (sebenarnya) ilmu-Nya meliputi apa yang ada pada mereka, dan Dia menghitung segala sesuatu satu persatu"

Orang yang mempunyai sifat ini akan menyampaikan dengan benar dan apa adanya dengan tutur kata yang tepat. Berbicara dengan orang lain dengan sesuatu yang mudah dipahaminya, berdiskusi dan melakukan presentasi dengan bahasa yang mudah dipahami sehingga orang tersebut dapat dengan mudah memahami pesan bisnis yang kita sampaikan.

4. Fathanah

Fathanah artinya Cerdas. Mustahil Nabi itu bodoh. Dalam menyampaikan 6 ribu lebih ayat Al Qur'an kemudian menjelaskannya dalam puluhan ribu hadits membutuhkan kecerdasan yang luar biasa. Nabi harus mampu menjelaskan firman-irman Allah kepada kaumnya sehingga mereka mau masuk ke dalam Islam. Nabi juga harus mampu berdebat dengan orang-orang kafir dengan cara yang sebaik-baiknya. Apalagi Nabi mampu mengatur ummatnya sehingga dari bangsa Arab yang bodoh dan terpecah-belah serta saling perang antar suku, menjadi satu bangsa yang berbudaya dan berpengetahuan. Dan dapat diartikan sebagai seorang pemasar harus cerdik dan bijaksana, dalam kata lain adalah pemasar harus mengerti, memahami, menghayati secara mendalam segala hal yang menjadi tugas dan kewajibannya.

\section{c. Prinsip-Prinsip Etika Bisnis Menurut Al- Qur'an:}

1) Melarang bisnis yang dilakukan dengan proses kebatilan (QS An-Nisa :29). 
2) Kegiatan bisnis juga memiliki fungsi sosial baik melalui zakat dan sedekah (QS. At-Taubah:34)

3) Melarang pengurangan hak atas suatu barang atau komoditas yang didapat atau diproses dengan media takaran.

4) Menjunjung tinggi nilai-nilai keseimbangan baik ekonomi maupun sosial, keselamatan dan kebaikan serta tidak menyetujui kerusakan dan ketidakadilan.

5) Pelaku bisnis dilarang berbuat zalim (curang) baik bagi dirinya sendiri maupun kepada pelaku bisnis yang lain (QS.Al-A'raf :85).

\section{Kajian Tentang Manajemen Bisnis Islam}

\section{a. Pengertian Bisnis dan Manajemen Bisnis Islam}

Bisnis adalah suatu kegiatan usaha individu yang terorganisasi untuk menghasilkan dan menjual barang dan jasa guna mendapatkan keuntungan dalam memenuhi dan memuaskan kebutuhan masyarakat (Sutarno, 2012:1).

Manajemen menurut pandangan Islam merupakan manajemen yang adil. Batasan adil adalah pimpinan tidak mengurangi atau tidak memaksa bawahan untuk bekerja melebihi ketentuan dan bawahan tidak mungkin pimpinan maupun perusahaan yang ditempati. Seharusnya kesepakatan kerja dibuat untuk kepentingan bersama antara pimpinan dan bawahan. Jika seorang manajer mengharuskan bawahan atau karyawannya bekerja melampaui waktu kerja yang ditentukan, maka sebenarnya manajer itu telah mendzalimi karyawannya. Dan ini sangat bertentangan dengan ajaran Islam.

Manajemen Islami harus didasari dengan nilai-nilai dan etika Islam. Islam yang ditawarkan berlaku universal tanpa mengenal ras dan agama. Boleh saja berbisnis dengan label Islam, namun bila nilai dan akhlak Islam dalam melakukan bisnis tersebut ditinggalkan, maka tidaklah lagi pantas dianggap sebagai Islam.

\section{b. Fungsi - Fungsi Manajemen}

\section{1) Perencanaan (Planning)}

\section{a) Definisi Perencanaan}

Perencanaan berasal dari kata rencana yang diberi imbuhan pe- dan -an. Rencana adalah produk dari perencanaan, sedangkan perencanaan adalah proses penentuan rencana. Perencanaan berasal dari bahasa latin yaitu Planus yang berarti flat. 
Pengertian perencanaan menurut G.R Terry dan LW. Rue:

"Proses memutuskan tujuan-tujuan apa yang akan dikejar selama suatu jangka waktu yang akan datang dan apa yang akan dilakukan agar tujuan-tujuan itu dapat tercapai".

Dalam Islam perencanaan merupakan kegiatan awal yang harus disusun dalam sebuah pekerjaan/organisasi guna mencapai hasil secara optimal. Sebagaimana firman Allah surah al-Hasyr ayat 18,yaitu

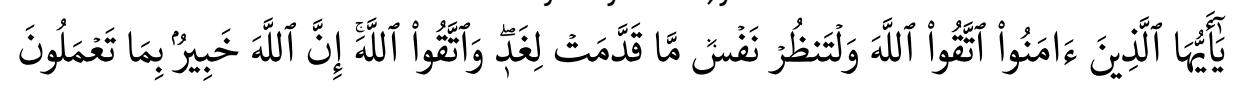

"Hai orang-orang yang beriman, bertakwalah kepada Allah dan hendaklah setiap diri memperhatikan apa yang telah diperbuatnya untuk hari esok (akhirat); dan bertakwalah kepada Allah, sesungguhnya Allah Maha Mengetahui apa yang kamu kerjakan"

\section{b) Jenis - jenis Perencanaan}

Dalam sebuah perencanaan terdapat banyak variasi atau jenis perencanaan, diantara beberapa jenis tersebut adalah visi, misi, tujuan, strategi, kebijakan, prosedur serta aturan.

\section{2) Pengorganisasian (Organizing)}

\section{a) Definisi Pengorganisasian}

Pengorganisasian merupakan fungsi manajemen yang bersifat dinamis dan merupakan proses untuk memperoleh organisasi yang menjadi alat atau wadah bagi manajer dalam melakukan aktivitas-aktivitasnya guna mencapai tujuan. Dalam fungsi pengorganisasian, manajer mengalokasikan keseluruhan sumber daya organisasi sesuai dengan rencana yang telah dibuat berdasarkan kerangka kerja organisasi tertentu. Kerangka kerja tersebut dinamakan desain organisasi sedangkan bentuk spesifik dari kerangka kerja organisasi dinamakan struktur organisasi.

Pada struktur organisasi tergambar posisi kerja, pembagian kerja, jenis kerja yang harus dilakukan, hubungan atasan dan bawahan, kelompok, komponen atau bagian, tingkat manajemen dan saluran komunikasi (Fattah, 2001:73). Hal ini menunjukkan bahwa ajaran Islam mendorong umatnya untuk melakukan segala sesuatu secara terorganisasi dengan rapi, firman Allah dalam surah ash-Shaff ayat 4 yaitu :

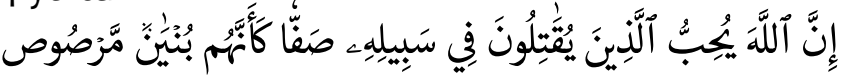


"Sesungguhnya Allah menyukai orang yang berperang dijalan-Nya dalam barisan yang teratur seakan-akan mereka seperti suatu bangunan yang tersusun kokoh"

\section{b) Proses Pengorganisasian}

Proses dapat disebut dengan langkah atau urutan kegiatan yang harus dilaksanakan. Menurut Malayu S.P Hasibuan proses pengorganisasian terdiri dari delapan tahap, yaitu:

1. Manajer harus mengetahui tujuan organisasi yang ingin dicapai, apakah profit, motive atau service motive.

2. Penentuan kegiatan-kegiatan, artinya manajer juga harus mengetahui, merumuskan serta menspesifikasikan kegiatan-kegiatan yang diperlukan untuk mencapai tujuan organisasi dan menyusun daftar kegiatan-kegiatan yang akan dilakukan.

3. Pengelompokan kegiatan, setelah kegiatan-kegiatan apa saja yang telah ditentukan maka hendaknya manajer mengelompokkan kegiatan-kegiatan tersebut kedalam beberapa kelompok atas dasar tujuan yang sama.

\section{3) Pengarahan (Actuating)}

\section{a) Pengertian Pengarahan}

Pengarahan merupakan istilah yang sering dikenal sebagai penggerakan atau pengawasan serta merupakan fungsi manajemen yang terpenting dan paling dominan dalam proses manajemen. Pengarahan dapat ditetapkan setelah adanya rencana, organisasi dan karyawan. Jika fungsi ini telah ditetapkan maka proses manajemen dalam merealisasikan tujuan dimulai.

\section{b) Aspek-aspek Pengarahan}

Agar suatu pengarahan dapat berhasil, perlu kiranya seorang atasan mengetahui aspek-aspek pokok pengarahan, adapun aspek-aspek pokok pengarahan tersebut yaitu:

1. Kepemimpinan, merupakan proses mengarahkan dan mempengaruhi aktivitas-aktivitas anggota kelompok yang berkaitan dengan tugasnya. Dalam kepemimpinan terdapat tiga unsur terpenting, yaitu: pimpinan, bawahan (pengikut) dan pembagian kekuasaan atau power (Wijayanti, 29).

2. Motivasi, menurut Bernard Berelson dan Gary A. Steiner mendefinisikan bahwa motivasi merupakan keadaan kejiwaan dan sikap mental manusia yang memberikan energi, mendorong kegiatan (moves) dan mengarah atau menyalurkan prilaku ke arah mencapai kebutuhan yang memberikan kepuasan atau keseimbangan (Siswanto, 2005:119). 
3. Mengembangkan komunikasi, merupakan kegiatan-kegiatan untuk saling memberi keterangan dan ide secara timbal balik, yang diperlukan dalam setiap usaha kerja sama manusia untuk mencapai tujuan tertentu.

\section{4) Pengendalian (Controling)}

\section{a) Definisi Pengendalian}

Pengendalian dalam pandangan Islam dilakukan untuk meluruskan yang tidak lurus, mengoreksi yang salah danmembenarkan yang hak. pengendalian (controlling) dalam ajaran Islam terbagi menjadi dua hal. Pertama, pengendalian yang bersumber dari diri sendiri yang bersumber dari tauhid dan keimanan kepada Allah SWT. Kedua, sebuah pengendalian yang berasal dari luar diri sendiri (sistem)

\section{b) Jenis-Jenis Pengendalian}

Mamduh M. Hanafi mengemukakan tiga jenis dasar pengendalian yaitu pengendalian pendahuluan, pengendalian ya/tidak dan pengendalian umpan balik.

1. Pengendalian pendahuluan, merupakan pengendalian yang cukup agresif dan memerlukan informasi yang akurat dan tepat waktu mengenai perubahan-perubahan dalam lingkungan atau kemajuan dalam mencapai tujuan tertentu. Adapun perubahanperubahan yang mungkin terjadi dan membuat realisasi rencana terhambat akan selalu diantisipasi.

2. Pengendalian concurrent (yes/no) merupakan pengendalian ketika suatu kegiatan akan terus dilanjutkan atau tidak apabila ada persetujuan atau ada kondisi tertentu yang harus dipenuhi. Tipe pengendalian ini kurang popular dibandingkan dengan tipe pengendalian pendahuluan, tetapi tipe pengendalian ini dapat digunakan sebagai pelengkap dan digunakan bersama-sama dengan pengendalian pendahuluan karena dengan adanya penggunaan bersama tersebut akan meningkatkan keamanan program atau kegiatan yang sedang dilakukan.

3. Pengendalian umpan balik (post-action control) pengendalian ini mengevaluasi hasil-hasil yang telah terjadi setelah suatu kegiatan selesai. Penyebab-penyebab penyimpangan kemudian ditentukan dan kemudian penyebab-penyebab tersebut dapat digunakan untuk perencanaan di masa mendatang untuk kegiatan yang serupa. 


\section{METODOLOGI PENELITIAN}

Penelitian ini menggunakan perspektif pendekatan kualitatif. Objek penelitian yang diambil oleh penulis adalah usaha kuliner Waroeng Steak and Shake yang ditinjau dari sisi etika bisnis Islam dan manajemen bisnis Islamnya. Secara khusus penelitian ini bertujuan untuk mengetahui, 1) konsep etika bisnis Islam di Waroeng Steak and Shake Cabang SM. Raja Medan. 2) konsep Manajemen Bisnis Islam di Waroeng Steak and Shake Cabang SM. Raja Medan.

Dalam penelitian ini, data diperoleh melalui dua sumber yaitu data primer dan data sekunder. Pengumpulan data dilakukan dengan, 1) Studi Pustaka Teknik Simak, 2) Observasi, 3) Wawancara Semi Berstruktur, 4) Dokumentasi

\section{Sejarah Waroeng Steak \& Shake}

Restoran steak ini didirikan oleh Jody Brotosuseno dan istrinya Siti Hariyani. Waroeng Steak and Shake berdiri dan dijadikan peluang usaha yang bagus dikarenakan stigma mahal yang sudah sangat melekat pada masakan eropa seperti steak. Konon steak hanya bisa dinikmati oleh kalangan menengah keatas, dari sinilah akhirnya timbul gagasan untuk membuat steak dengan harga yang terjangkau oleh kantong mahasiswa dan masyarakat menengah kebawah. Akhirnya pada tanggal 4 September tahun 2000 berdirilah outlet yang bernama Waroeng Steak and Shake di jalan Cendrawasih Demangan Yogyakarta. Dibukanya Waroeng Steak and Shake merupakan sebuah terobosan baru steak dengan harga yang murah dan rasa yang tidak kalah enak dan nikmat dengan steak yang dijual dengan harga mahal. Selain itu Waroeng Steak and Shake selalu mengutamakan kehalalan semua bahan-bahan makanan dan semua jenis minuman. Meski dengan bahan-bahan lokal, Waroeng Steak and Shake mampu menyajikan citarasa tinggi khas Eropa dengan harga yang menjangkau masyarakat Indonesia.

\section{Etika Bisnis Islam Waroeng Steak and Shake Cabang SM Raja Medan}

Dalam etika bisnis Islam, ada 4 prinsip sifat dasar Rasulullah saw yang harus dimiliki yaitu Shiddiq (kejujuran), Amanah (bertanggungjawab dan dapat dipercaya), Tabligh (menyampaikan), dan Fathanah (cerdas).

\section{Shiddiq (kejujuran)}

Sikap jujur yang diterapkan oleh Waroeng Steak and Shake Cabang SM Raja Medan dalam menjalankan bisnis kulinernya meliputi hal-hal berikut:

\section{a. Menjamin bahan baik dan halal}


Salah satu hal yang perlu diperhatikan mengenai kehalalan menu steak adalah bahan utamanya yang berupa daging sapi atau daging ayam. Haruslah dipastikan bahwa daging tersebut diproses dengan cara penyembelihan halal. Selain daging, campuran bumbu, alat, cara memasak juga tak boleh luput dari pengawasan, karena hal-hal tersebut juga menentukan kehalalan masakan. Waroeng Steak and Shake menjamin bahwa daging yang mereka gunakan adalah daging dengan kualitas bagus, juga dijamin kehalalannya karena pihak supplier daging yang mereka ajak bekerja sama adalah supplier yang memiliki pemahaman agama yang baik begitu juga dengan penerapannya. Seperti penuturan Yusuf (Supervisor Outlet, Waroeng Steak and Shake, wawancara dilaksanakan di Medan, 8 November 2016 )

Disini kami menjamin bahwa daging yang kami gunakan adalah daging yang disembelih dengan menyebut dengan nama Allah. Kami juga memilih supplier yang kami percaya beragama Islam yang baik. Selain daging, sayuran yang kami pakai juga sayuran yang fresh. Penyuplai sayuran langsung mengantarkan sayuran setiap harinya ke outlet. Kami juga bisa lebih meyakinkan konsumen dengan mendaftarkan produk kami di LPPOM MUI dan alhamdulillah kami sudah bersertifikat Halal MUI.

Peneliti juga melakukan wawancara dengan Putri (pelanggan Waroeng Steak and Shake, wawancara dilakukan di medan 25 Januari 2017),

Saya sudah berkali-kali datang ke Waroeng Stean and Shake yang di cabang SM Raja ini, alhamdulillah pesanan saya selalu bagus. Dagingnya enggak keras dan enggak ada bau yang aneh. Soalnya kalau dagingnya kurang segar pasti ada aroma yang kurang sedap. Bumbunya juga enak. Hanya saja kuah steaknya saya rasa sedikit. Dan lama juga nunggu pesanan saya datang.

Dengan telah terdaftarnya produk Waroeng Steak and Shake di LPOM MUI dan lulus mendapatkan sertifikat Halal maka konsumen akan lebih tenang untuk membeli di Waroeng Steak and Shake. Dengan begitu Warong Steak and Shake telah jujur dalam menjual produknya kepada konsumen bahwa bahan yang mereka gunakan benar baik dan halal.

b. Jujur dalam bertransaksi

Menerapkan sifat jujur dalam berbisnis merupakan hal yang sangat penting. Karena Allah memerintahkan hambaNya untuk selalu memiliki sifat jujur, juga dengan adanya sifat jujur ini akan mendatangkan keberkahan dalam bisnis. 
Waroeng Steak and Shake berusaha unuk selalu mengajarkan karyawannya bersikap jujur dalam menjalankan tugasnya. Dan hal itu tampak dalam hasil wawancara penulis dengan Delvi (pelanggan Waroeng Steak and Shake, wawancara dilakukan di medan 25 Januari 2017)

Saya suka ngumpul dengan teman-teman itu di Waroeng Steak and Shake ini karena saya pernah punya pengalaman baik disini. Pernah saya mesan jus, ternyata ketika baru sedikit saya minum lalat masuk kedalam gelasnya. Saya langsung memanggil karyawan untuk kembali memesan minuman yang sama. Pada saat membayar ternyata minum yang saya bayar itu hanya satu. Minuman kedua yang saya pesan tidak masuk kedalam hitungan. Setelah saya konfirmasi ke kasir ternyata mereka mengganti minum saya yang dimasuki lalat tersebut. Jadi saya menilai mereka berbisnis dengan jujur.

Jujur dalam bertransaksi juga berarti pihak manajemen Waroeng Steak and Shake tidak menjual steak dari daging yang tidak layak dijadikan steak. Dalam hal ini tidak layaknya bukan karena dagingnya tidak bagus tetapi misalnya dalam hal salah potong ukuran. Suwanda (karyawan bagian dapur, wawancara dilakukan di Medan 22 Januari 2017) menjelaskan bahwa:

Disini, daging yang salah potong tidak akan kami gunakan untuk membuat steak. Tetapi tidak akan kami buang juga. Nah, daging yang salah potong tersebut kami sebut tetelan. Disini, tetelan itu dijual kembali dengan harga yang murah. Banyak karyawan yang biasa beli untuk dimasak sendiri. Akan tetapi untuk tetelan itu kan enggak setiap hari ada. Hanya ketika ada daging yang salah potong saja sehingga enggak mungkin dimasak untuk konsumen.

\section{Amanah}

Sikap bertanggung jawab dan dapat dipercaya yang ditampilkan Waroeng Steak and Shake Cabang SM Raja Medan meliputi hal-hal berikut:

\section{a. Akuntabilitas}

Berdasarkan hasil wawancara dengan D (karyawan bagian keuangan Waroeng Steak and Shake, wawancara dilakukan di Medan 14 September 2016)

Waroeng Steak and Shake setiap harinya membuat laporan keuangan pemasukan dan pengeluaran outlet. Semua itu akan dilaporkan setiap harinya ke ketua keuangan. Lalu diteruskan melalui email ke pusat di Yogyakarta. 
Dari hasil wawancara tersebut dapat diketahui bahwa Waroeng Steak and Shake Cabang SM Raja Medan memiliki catatan atas transaksi keuangannya. Hal ini dimaksudkan untuk mengetahui berapa jumlah keuntungan maupun kerugian yang diterimanya dalam jangka waktu tertentu. Akuntansi merupakan salah satu bentuk pertanggungjawaban kepada penanggungjawab keuangan. Akuntabilitas sebagai perwujudan sifat amanah dari kepala bagian keuangan kepada pemilik Waroeng Steak and Shake. laporan pertanggungjawaban ini pun menjadi tolok ukur bagi Waroeng Steak and Shake Cabang SM Raja Medan, mengalami kemajuan ataukah kemunduran. Sehingga sangat penting sifat ini diterapkan dan diaplikasikan dalam suatu bisnis.

\section{b. Tanggungjawab sosial}

Sikap bertanggungjawab yang dimiliki oleh Waroeng Steak and Steak diantaranya adalah tanggungjawab sosial. Beberapa kegiatan sosial yang telah dilaksanakan oleh Waroeng Steak and Shake antara lain:

\section{Penyaluran Dana Bantuan}

Setiap setengah tahun sekali pihak Waroeng Steak and Shake mengadakan penyaluran bantuan untuk daerah yang kurang mampu. Bantuan bisa saja disalurkan melalui sekolah atau langsung ke masyarakatnya. Dalam kesempatan ini penulis berkesempatan untuk mengikuti kegiatan penyaluran dana bantuan ke Sekolah Yayasan Perguruan Nurul Iman Karya Maju di daerah Tanjung Pura, Langkat. Kegiatan diadakan pada tanggal 1 Juni 2016.

2. Berbagi Parcel lebaran untuk para dhuafa

3. Kegiatan Bantuan Untuk Korban Bencana Alam

Seorang pengusaha yang menginginkan keuntungan tentunya harus mengeluarkan modal. Begitu juga jika ingin mendapatkan rezeki yang berlipat ganda, kita harus mengeluarkan modal, yaitu "meminjamkan" sebagian dari harta kita kepada Pemberi Rezeki melalui sedekah. Allah akan membalas pinjaman itu dengan melapangkan jalan rezeki yang tidak kita ketahui. Ini janji Allah SWT dalam QS. Al-Hadid: 18:

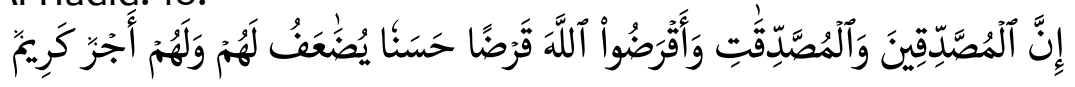

"Sesungguhnya orang-orang yang bersedekah baik laki-laki maupun perempuan dan meminjamkan kepada Allah dengan pinjaman yang baik, niscaya akan dilipatgandakan (pahalanya) kepada mereka dan bagi mereka pahala yang banyak" 


\section{Memberikan Pelayanan yang Optimal}

Waroeng Steak and Shake Cabang SM Raja Medan berusaha memberikan pelayanan terbaik kepada konsumen, artinya bahwa konsumen sebagai raja dan konsumen diprioritaskan dalam terciptanya kebutuhan mereka. Yaitu dengan cara memberikan pelayanan yang tepat dan cepat, murah senyum, serta pelayanan ramah. Rasulullah sangat menganjurkan para pelaku bisnis untuk bermurah hati dalam setiap transaksi, murah senyum dan ramah tamah.

Herlinayanti Harahap (wawancara dilakukan di Medan tanggal 15 Agustus 2016) salah seorang pelanggan Waroeng Steak \& Shake Cabang SM. Raja Medan mengatakan:

Pelayanan yang diberikan kurang memuaskan, lambat dan kurang care terhadap pelanggan. Mungkin lambat karena saya datang disaat jam makan siang jadi ramai, ya walaupun begitu setidaknya kalau saja karyawannya lebih care dengan pelanggan perasaan kurang memuaskan karena pesanan datang lama lebih terobati.

Dalam setiap usaha bisnis yang dilakukan, pelayanan terhadap konsumen merupakan hal yang sangat membutuhkan perhatian khusus karena salah satu faktor yang bisa mempertahankan keberlangsungan usaha adalah kepuasan konsumen terhadap pelayanan yang diberikan. Akhlak tolak ukurnya dengan menggunakan Al-Qur'an dan Sunnah. Jadi, segala tindakan yang dilakukan oleh semua jajaran manajemen haruslah sesuai dengan tuntunan Al-Qur'an dan Sunnah. Dan terpatri di dalam hati di setiap masing-masing karyawan.

Menurut Yusuf (Supervisor Outlet, Waroeng Steak and Shake, wawancara dilaksanakan di Medan,tanggal, 15 Mei 2016)

Disini kami berusaha untuk memberikan pelayanan terbaik untuk konsumen. Walaupun terkadang belum maksimal. Namun, kami menekankan kepada karyawan untuk menjaga akhlak yang baik. Misalnya, mampu menahan emosi dalam berinteraksi baik itu kepada sesama karyawan maupun kepada konsumen. Walaupun dalam posisi konsumen yang salah, namun karyawan wajib menyelesaikan setiap masalah dengan nada yang halus dan sopan. Karena, kami menganggap konsumen adalah raja sehingga harus diperlakukan dengan baik. 
Kesimpulannya adalah pelayanan yang diberikan kepada konsumen masih membutuhkan perhatian khusus oleh manajemen Waroeng Steak and Shake. Dengan memperbaiki pelayanan yang diberikan diharapkan akan meningkatkan kepuasan konsumen.

\section{d. Menepati Janji}

Sesuai dengan dasar perusahaan yaitu Spritual Company, Waroeng Steak and Shake konsisten memberangkatkan karyawan umroh di setiap tahunnya. Maksud dari Spiritual Company disini adalah segala hal yang dilakukan perusahaan sesuai dengan ajaran agama Islam di keseharian para karyawan. Terdapat 20 karyawan yang di berangkatkan umroh pada tahun ini. Karyawan tersebut berasal dari berbagai wilayah seperti Medan, Lampung, Bandung, Cirebon, Surabaya, Yogyakarta dan Malang. Umroh tahun 2016 adalah umroh ke-6 yang dilaksanakan Waroeng Steak and Shake untuk karyawannya. Kegiatan umroh dilaksanakan pada 12-20 Maret 2016. Program ini merupakan sumbangsih perusahaan serta bentuk motivasi kepada karyawan agar tidak hanya masalah duniawi saja yang dikejar melainkan harus seimbang antara dunia dan akhirat.

Yusuf (supervisor outlet Waroeng Steak and Shake, wawacara dilakukan di Medan tanggal 15 Juni 2016)

Pemilik Waroeng Steak and Shake selalu rutin mengumrohkan karyawan yang memang terpilih untuk diberikan umroh gratis. Jadi kupon itu sangat berguna bagi karyawan. Setiap karyawan berlomba untuk mendapatkan kupon tersebut dengan rajin menyetor 4 Surah yang sudah dipilih. Selanjutnya kupon tersebut dikumpulkan untuk kemudian diundi siapa pemenang umroh setiap tahunnya.

Seluruh karyawan Waroeng Steak and Shake memiliki kesempatan yang sama untuk memenangkan undian berhadiah umroh ini. Tentunya, terdapat persyaratan yang harus dipenuhi oleh setiap karyawan. Persyaratannya adalah karyawan cukup menghafal beberapa surat Al-Quran yaitu surat Yasin, Al Mulk, Al Waqiah dan Ar Rahman. Karyawan yang hafal satu surat berhak atas 1 kupon undian umroh, begitupun jika ada yang sampai hafal empat surat berarti mendapatkan 4 kupon undian umroh. Undian umroh tersebut diundi pada saat acara syawalan (halal bihalal) keluarga besar Waroeng Steak and Shake. Diharapkan dengan program ini karyawan menjadi lebih termotivasi untuk lebih dekat dengan Al Quran. 


\section{Tabligh}

Komunikatif dan argumentatif yang ditampilkan oleh Waroeng Steak and Shake Cabang SM Raja Medan meliputi hal-hal berikut:

\section{a. Komunikasi Bisnis}

Dari hasil observasi peneliti dapat menyimpulkan bahwa dalam berkomunikasi dengan konsumen Waroeng Steak and Shake Cabang SM Raja Medan sudah menggunakan bahasa yang sopan dan halus. Namun ada beberapa hal yang menjadi kelemahan dalam segi komunikasi ini. Seperti penuturan Wika (pelanggan , wawancara dilakukan di Medan 15 Januari 2017)

Sebenarnya bahasa yang digunakan sudah baik, hanya saja akan lebih baik jika dari datang dan selesai konsumen itu di sambut. Misalnya, dengan mengucapkan terimakasih ketika kita hendak meninggalkan outlet.

Sejalan dengan itu menurut Yani (pelanggan , wawancara dilakukan di Medan 15 Januari 2017)

Kalau saya menilainya pelayanan disini masih biasa saja. Misalnya, saat memberi menu, hanya memberikan draft menu lalu hanya bilang, mau pesan apa kak? Kalau misalnya dijelaskan tentu akan lebih baik. Misalnya ini menunya mbak, mbak mau pesan apa ya? Menu favorit disini ini dan ini mbak, jadi bisa rekomendasi menu ini untuk dipesan. Minuman yang paling recomended yang ini mbak. Nah, begitu kan enak.

Kesimpulan yang dapat diambil adalah, komunikasi bisnis Waroeng Steak and Shake masih harus diperbaiki lagi. Karena dengan menjalin hubungan komunikasi yang baik dan interaksi yang menyenangkan dengan pelanggan dapat membentuk reputasi perusahaan yang baik. Dengan begitu, pelanggan dapat menilai kualitas dan kredibilitas perusahaan dalam melayani pelanggan. Bahkan profesionalitas layanan dari perusahaan akan dinilai positif di mata konsumen sehingga pelanggan akan bertambah dan menjadi customer yang setia.

\section{b. Dakwah}

\section{1). Simbol-Simbol}

Waroeng Steak and Shake banyak melekatkan label Islam dalam menjalankan bisnisnya. Misalnya, dengan melekatkan gambar-gambar yang sarat dengan 
nilai keislaman, contoh gambar yang bertuliskan makanlah dengan tangan kanan. Dalam hal ini karena Steak yang berasal dari negara Barat biasanya dikonsumsi dengan cara memegang garpu ditangan kiri dan pisau untuk memotong steak di tangan kanan. Sehingga otomatis tangan kiri yang memegang garpulah yang akan digunakan untuk makan. Akan tetapi hal tersebut tidaklah sesuai dengan ajaran Islam yang mengharuskan makan dengan tangan kanan. Sehingga melalui media yang dilekatkan di dinding outlet yang bertuliskan makanlah dengan tangan kanan, pihak manajemen berusaha untuk mengingatkan konsumen agara tetap makan sesuai dengan ketentuan Islam.

2). Mengumandangkan adzan setiap waktu shalat tiba

Contoh lainnya adalah adanya adzan di setiap waktu shalat sehingga mengingatkan koonsumen bahwa waktu shalat telat tiba dan bergegas untuk segera melaksanakan shalat. Selain untuk mengingatkan konsumen, jika waktu adzan telah tiba maka para karyawan juga akan bergantian untuk melaksanakan shalat.

3). Menyediakan mushalla, Al-Qur'an, sajadah, sarung dan mukena

Pihak manajemen juga menyediakan mushalla untuk melaksanakan ibadah shalat bagi karyawan outlet pengunjung yang beragama Islam. Tak lupa pihak manajemen menyediakan mukenah bagi pengunjung perempuan yang hendak shalat. Tak lupa juga menyediakan sajadah, sarung serta Al-Qur'an.

4). Mengadakan hari bebas rokok nasional

Setiap tanggal 31 Mei, manajemen Waroeng Steak and Shake mengadakan hari Bebas asap rokok diseluruh outlet.

\section{5). Tabligh Akbar}

Kegiatan Tabligh Akbar adalah kegiatan pengajian rutin tiap sebulan sekali yang dilaksanakan oleh pihak manajemen Waroeng Steak and Shake. Sasaran pesertanya selain dari internal Waroeng Steak and Shake adalah masyarakat sekitar lingkungan Waroeng Steak and Shake. Tujuan kegiatan ini adalah untuk mempererat hubungan silaturrahmi antara pihak Waroeng Steak dengan masyarakat sekitar outlet.

\section{Fathanah (Kecerdasan)}

Kecerdasan yang ditunjukkan oleh Waroeng Steak and Shake Cabang SM Raja Medan meliputi hal-hal berikut: 
a. Kecerdasan spiritual

Kecerdasan spiritual yang dilakukan yaitu dalam bentuk menjalankan sholat wajib,dan melaksanakan sholat sunnah dhuha. Beberapa hal yang mencakup penerapan ibadah di Waroeng Steak and Shake antara lain adalah pengerjaan shalat 5 waktu dan lebih baik lagi apabila ditambah dengan shalat sunnahnya. Di outlet Waroeng Steak and Shake Cabang SM Raja, pelaksanaan shalat fardhu oleh segenap karyawan terus dilakukan perbaikan. Beberapa usaha yang dilakukan pihak manajemen untuk memperbaiki ibadah wajib shalat fardhu diantaranya adalah dengan secara bergantian menugaskan karyawannya pada waktu subuh untuk piket membangunkan shalat subuh untuk teman-temannya.

\section{Manajemen Bisnis Islam Waroeng Steak \& Shake}

\section{a. Planning (Perencanaan)}

\section{Visi dan Misi}

Waroeng Steak and Shake memiliki visi yaitu Perubahan yang lebih baik sesuai dengan syariah. Akan lebih baik jika dijelaskan lebih spesifik tentang perubahan dalam hal apa yang diinginkan. Misalnya dengan membuat Visi seperti Menjadikan Waroeng Steak and Shake sebagai superbrand kuliner dari Indonesia yang mendunia, halal \& toyyib dengan era spiritual manajemen.

Yusuf (Supervisor Outlet, Waroeng Steak and Shake, wawancara dilaksanakan di Medan, 8 November 2016) mengemukakan Waroeng Steak and Shake memiliki misi antara lain:

a) Menjadikan perusahaan sebagai sarana untuk mendapatkan ridhoNya Allah SWT dan keberadaanNya selalu bisa bermanfaat untuk banyak orang.

b) Mencanangkan tanggungjawab sosial demi kehidupan yang lebih baik.

c) Bekerja adalah ibadah, tanpa melepaskan unsur tanggungjawab dan disiplin yang tinggi.

d) Menjadikan karyawan perusahaan yang berakhlak mulia dan taat beribadah.

e) Membangun usaha yang halal, berdaya guna dan berkualitas tinggi, yang berorientasi pada pelayanan terbaik.

f) Menghasilkan profit, membangun citra, mengembangkan profesionalisme usaha berdasarkan prinsip-prinsip keislaman.

Misi adalah upaya yang dilakukan untuk mencapai visi. Penulis menawarkan misi yang lebih sesuai untuk konteks upaya adalah: 
a) Mengoptimalkan perusahaan sebagai sarana untuk bekerja dan beribadah.

b) Berperan aktif untuk melaksanakan tanggung jawab sosial

c) Mengoptimalkan tanggung jawab dan disiplin yang tinggi

d) Membangun perusahaan dengan mengajak seluruh karyawan lebih meningkatkan kualitas ibadah dan meningkatkan kualitas akhlak

e) Membangun usaha halalan tayyiban dengan kualitas tinggi dan pelayanan terbaik

f) Meningkatkan profit, profit, membangun citra, mengembangkan profesionalisme usaha berdasarkan prinsip-prinsip keislaman.

\section{Produksi}

Hal yang paling utama dalam hal produksi yaitu menjamin bahwa bahan makanan yang digunakan adalah bahan yang baik dan terjamin kehalalannya. Waroeng Steak and Shake tentu seluruhnya menggunakan bahan berupa daging, baik itu daging sapi maupun daging ayam. Menurut E (karyawan bagian dapur pusat Waroeng Steak and Shake, wawancara dilakukan di Medan 14 September 2016)

Setiap bahan daging yang masuk itu adalah daging yang segar. Dan penyembelihannya juga dilakukan secara Islami. Untuk sayuran setiap hari selalu datang pemasok sayur yang kami pilih untuk bekerja sama. Sayur yang diantar adalah sayuran masih fresh. Setiap hari berganti stok sayuran disini.

Dalam hal ini, Outlet Waroeng Steak menjamin bahwa bahan yang digunakan untuk disajikan kepada konsumen adalah bahan yang baik dan terjamin halalnya. Salah satu usaha yang dilakukan pihak manajemen Waroeng Steak and Shake adalah dengan mendaftarkan outlet mereka untuk diperiksa oleh pihak MUI agar mendapatkan sertifikat Halal MUI sehingga konsumen tidak lagi ragu untuk mengkonsumsi produk dari Waroeng Steak and Shake. Seperti penuturan Yusuf (Yusuf, Supervisor Outlet, Waroeng Steak and Shake, wawancara dilaksanakan di Medan, 8 November 2016)

Disini kami menjamin bahwa daging yang kami gunakan adalah daging yang disembelih dengan menyebut dengan nama Allah. Kami juga memilih supplier yang kami percaya beragama Islam yang baik. Selain daging, sayuran yang kami pakai juga sayuran yang fresh. Penyuplai sayuran langsung mengantarkan sayuran setiap harinya ke outlet.

Kemudian, pihak manajemen juga bekerja sama dengan pihak supplier daging sapi dan daging ayam yang mereka percaya bahwa supplier tersebut beragama Islam dan menyembelih dengan menyebut nama Allah. Di Outlet 
Waroeng Steak and Shake Cabang SM Raja Medan memiliki 5 supplier untuk menyuplai daging sapi dan 4 supplier untuk menyediakan daging ayam.

Pemesanan dilakukan setiap malam hari dengan menggunakan SOP (Surat Orderan Pesanan). Waroeng Steak and Shake bekerja sama dengan beberapa supplier bukan hanya dengan satu supplier dikarenakan tidak setiap hari supplier tersebut mampu mensuplai pesanan daging yang dibutuhkan oleh Waroeng Steak and Shake.

Untuk saat ini setiap harinya Waroeng Steak and Shake Cabang SM Raja membutuhkan setidaknya $30 \mathrm{~kg}$ daging ayam khusus untuk outlet Steak and Shake Cabang SM. Raja dan 8okg daging sapi setiap harinya untuk dibagi ke 3 cabang Outlet Waroeng Steak and Shake yang ada di Medan yaitu Waroeng Steak and Shake Cabang Adam Malik (Outlet 1), Waroeng Steak and Shake Cabang Wahid Hasyim (Outlet 2) dan Waroeng Steak and Shake Cabang SM Raja (Outlet 3). Dari ketiga Outlet Waroeng Steak and Shake yang ada di Medan, hanya terdapat satu dapur pusat saja yaitu dapur pusat yang berada di Waroeng Steak and Shake cabang SM Raja Medan karena disinilah ditetapkan sebagai pusat Waroeng Steak and Shake Wilayah Sumatera Utara. Sedangkan untuk dapur outlet tersedia di masing-masing cabang.

\section{Distribusi}

Pada bagian distribusi dilaksanakan oleh bagian minum dan bagian depan. Pada bagian minum beranggotakan 3 orang yang bertugas membuat minuman. Sedangkan pada bagian depan beranggotakan 7 orang yang bertugas untuk membersihkan lantai baik di ruangan $A C$ maupun non AC, menyiapkan saus, membersihkan meja, memotong dan merapikan tisu, mencuci peralatan seperti gelas, nampan dan lainnya, megisi lada dan mengantarkan pesanan ke meja konsumen.

Selanjutnya yang akan dibahas adalah mengenai manajemen Sumber Daya Manusia yang dilakukan di Waroeng Steak and Shake Cabang SM Raja Medan. Disini yang akan dibahas adalah mengenai perekrutan dan jenjang karir.

\section{Perekrutan Karyawan}

Dalam hal rekrutmen, Waroeng Steak and Shake telah mendekati praktik manajemen Islami. Hal ini terlihat dengan adanya proses rekrutmen yang tertu- 
tup, perekrutan karyawan Waroeng Steak and Shake tidak dibuka secara terbuka. Melainkan masih dalam lingkup internal saja. Selain itu mengharuskan Muslim sebagai syarat wajib pendaftaran, sehingga lebih terjamin kepribadian Islamnya sesuai dengan apa yang perusahaan harapkan.

\section{Jenjang Karir}

Tidak sulit untuk menaikkan jenjang karir di Waroeng Steak and Shake. Apabila nilai rapor karyawan dalam beberapa kurun waktu mengalamai peningkatan, maka pihak manajemen akan melakukan evaluasi apakah karyawan tersebut dapat diberikan amanah jabatan yang lebih tinggi. Dan sebaliknya apabila nilai rapor terus menurun maka langkah awal yang dilakukan supervisor adalah mencari tahu apa kendala atau masalah yang dialami karyawan tersebut lalu mengambil kebijakan berdasarkan hasil dari diskusi dengan karyawan tersebut.

\section{b. Organizing (Pengorganisasian)}

Dalam pengorganisasian, pemilik Waroeng Steak and Shake yaitu Bapak Jody Brotosuseno berperan sebagai direktur langsung di perusahaan ini. Sebelumnya beliau hanya menjabat sebagai pemilik saja, namun setahun belakangan ini beliau yang langsung mengawasi jalannya usaha kuliner tersebut.

Kemudian setiap outlet di cabang memiliki pimpinan yang disebut supervisor sebagai penanggungjawab outlet yang bertanggungjawab memberikan laporan perkembangan outlet ke Manajer Operasional yang ada di Yogyakarta. Supervisor di outlet Cabang SM Raja Medan adalah Bapak Yusuf. Lalu utk bagian keuangan diketuai oleh Wira Satria yang bertugas untuk mengaudit dan melaporkan keuangan perusahaan kepada Ibu Siti Haryani di Yogyakarta.

\section{c. Actuating (Pelaksanaan)}

\section{1) Ketepatan Waktu}

Mimi Anggreini (wawancara dilakukan di Medan tanggal 11 Agustus 2016) salah seorang pelanggan Waroeng Steak and Shake SM Raja mengatakan:

Makanannya enak. Hanya saja pelayanannya kurang memuaskan. Menu yang dipesan cenderung lama diantar ke konsumen. Apa karena kurang pegawai ya? Menurut saya apa sebaiknya pegawainya ditambah saja.

Herlinayanti Harahap (wawancara dilakukan di Medan tanggal 15 Agustus 
2016) salah seorang pelanggan Waroeng Steak \& Shake Cabang SM. Raja Medan juga mengatakan:

Pelayanan yang diberikan kurang memuaskan, lambat dan kurang care terhadap pelanggan. Mungkin lambat karena saya datang disaat jam makan siang jadi ramai, ya walaupun begitu setidaknya kalau saja karyawannya lebih care dengan pelanggan perasaan kurang memuaskan karena pesanan datang lama lebih terobati ya.

Ketepatan waktu dalam hal pengantaran menu yang dipesan merupakan point penting dalam hal bisnis kuliner. Jika sudah terjadi komplain atas keterlambatan pengantaran menu yang dipesan maka akan mengurangi nilai kepuasan pelanggan. Hal inilah yang masih harus menjadi bahan perhatian yang harus diperbaiki oleh manajemen dan karyawan Waroeng Steak Cabang SM Raja Medan. Terlebih lagi ketika jam ramai outlet seperti ketika jam makan dan saat berbuka puasa.

2) Apresiasi

Manajemen Waroeng Steak and Shake begitu memperhatikan dan mengapresiasi SDM terbaiknya melalui hadiah pemberangkatan umroh bagi karyawannya yang mampu menghafal beberapa surat Al-Quran yang ditentukan dan tentunya yang mempunyai kualitas kinerja terbaik. Sehingga, dengan adanya apresiasi tersebut diharapkan akan terciptanya loyalitas dan menumbuhkan semangat kerja yang tinggi dari para karyawannya.

\section{Spiritual Company}

Selain berusaha mengembangkan strategi bisnis, Waroeng Steak and Shake juga mulai mengembangkan program spiritual, yaitu perusahaan mulai memperhatikan asasasas agama dan tanggung jawab sosial. Sehingga akhirnya pada tanggal 10 September 2010 atau bertepatan dengan 1 Syawal 1423 H dibuatlah konsep bernama Spritual Company.

Kegiatan Spiritual Company

1. Pelaksanaan pengajian rutin mingguan

2. Setiap hari wajib shalat dhuha

3. Setiap hari diadakan tadarus bareng

4. Kegiatan menghafal Alquran setiap hari Selasa dan Kamis dan telah disediakan ustadz atau guru khusus untuk membimbingnya. 


\section{d. Controlling (Pengawasan)}

1. Briefing

Sebelum memulai kerja semua meluruskan niat karena Allah SWT semata. Dan sebelum mulai kerja ada penyatuan visi misi seperti training penyemangat sebelum kerja dalam bentuk briefing pagi. Seperti penuturan Nawan (karyawan bagian minum, wawancara dilaksanakan di Medan,tanggal 10 Oktober 2016)

Setiap pagi sebelum melaksanakan kerjaan, kami selalu berkumpul dulu. Selain mengadakan doa bersama, juga ada pemberian semangat oleh supervisor. Saling mengingatkan untuk tetap bekerja sambil beribadah. Setelah itu kami shalat dhuha berjamaah, lalu ada baca Al-quran sejenak. Baru kami kembali melaksanakan tugas masing-masing.

Sebelum kerja semua jajaran manajemen dari yang teratas sampai yang di paling bawah wajib buat sholat dhuha. Dan shalat dhuha menjadi SOP perusahaan. Dan saat dhuha tersebut semua jajaran Waroeng Steak and Shake diminta untuk berdoa agar Allah melancarkan rezeki Waroeng Steak and Shake. Akmal (ketua bagian dapur outlet, wawancara dilaksanakan di Medan, tanggal 11 Agustus 2016)

Disini, setiap pimpinan harus memberikan contoh dulu kepada bawahannya agar bawahannya juga melihat bahwa pimpinan tidak hanya memberikan perintah saja untuk shalat dhuha, tetapi disini pimpinan langsung bertindak sebagai imam shalat. Jadi pimpinan dahulu yang dibenerin akhlaknya baru bawahan pasti mengikut.

2. Peraturan Umum

a) Setiap karyawan dilarang untuk merokok dilokasi outlet, apabila karyawan diketahui melanggarnya maka tindakan yang dilakukan adalah akan dikeluarkan langsung dari outlet.

b) Setiap karyawan yang tidak ikut kegiatan spiritual company untuk sanksi pertama adalah denda senilai Rp 50.000,- lalu untuk pelanggaran kedua kalinya akan dikenakan Surat Peringatan 1 apabila masih terus dilanggar maka akan dikeluarkan dari outlet.

c) Setiap karyawan yang terlambat masuk kerja untuk sanksi pertama adalah denda senilai Rp 50.000,- lalu untuk pelanggaran kedua kalinya akan dikenakan Surat Peringatan 1 apabila masih terus dilanggar maka akan dikeluarkan dari outlet.

d) Setiap karyawan tidak masuk kerja tanpa ada keterangan untuk sanksi pertama 
adalah dikenakan Surat Peringatan 1 apabila masih terus dilanggar maka akan dikeluarkan dari outlet.

\section{SIMPULAN}

Berdasarkan hasil dari penelitian pada bab IV, maka dapat ditarik kesimpulan sebagai berikut:

Pertama, konsep etika bisnis Islam dalam Waroeng Steak and Shake Cabang SM Raja Medan sudah baik dari segi konsep Shiddiq yaitu dalam hal menjamin bahan baik dan halal serta kejujuran dalam bertransaksi serta Tabligh dalam hal dakwah. Namun ada kelemahan dari segi Amanah yakni dalam hal pelayanan dan Fathanah dalam hal kecerdasan spiritual. Untuk itu peneliti menawarkan program 3S (Senyum, Salam dan Sapa) untuk memperbaiki pelayanan dan kegiatan shalat berjamaah secara bershift di waktu Dzuhur, Ashar dan Maghrib untuk memperbaiki kecerdasan spiritual.

Kedua, konsep manajemen bisnis Islam dalam Waroeng Steak and Shake sudah dalam kategori baik dalam hal perencanaan yaitu: produksi, distribusi, perekrutan karyawan dan jenjang karir. Namun ada kelemahan dalam visi dan misi. Visi dan misi Waroeng Steak and Shake harus lebih ditegaskan lagi kemana arah tujuannya agar lebih jelas dan spesifik.

Untuk bagian pengorganisasian dalam hal pembagian tugas sudah masuk dalam kategori baik. Pihak manajemen membagi ke dalam dua bagian besar yaitu bagian outlet dan kantor. Sehingga pembagian kerja lebih spesifik dan teratur.

Kemudian untuk bagian pengawasan juga sudah dalam kategori baik yaitu dengan rutin mengadakan briefieng setiap pagi serta melaksanakan setiap peraturan yang berlaku tanpa memandang siapa yang melakukan kesalahan, baik itu manajer atau karyawan biasa apabila melakukan kesalahan maka hukuman yang diterima tidak akan dibedakan. Kelemahan dalam hal pengawasan adalah masih belum terbiasanya konsumen memberikan kritik dan saran yang membangun untuk Waroeng Steak and Shake dikarenakan sarana kritik dan saran masih sederhana yaitu dengan menulis di kertas lalu memasukkannya ke kotak kritik dan saran yang disediakan. Peneliti menawarkan program Teknologi kritik dan saran melalui website resmi Waroeng Steak and Shake. Konsumen dengan mudah masuk ke website resmi Steak and Shake lalu memberikan kritik dan sarannya. Dengan begitu pihak manajemen Waroeng Steak dapat mengetahui hal apa sajakah yang harus diperbaiki untuk terus meingkatkan kualitas pelayanan Waroeng Steak and Shake. 
Rizka Ar Rahmah: Etika dan Manajemen

Bagian terakhir yang diteliti adalah mengenai pelaksanaan. Dalam hal pelaksanaan juga sudah baik yaitu dalam bentuk apresiasi dan spiritual company namun ada kelemahan yaitu dalam hal ketepatan waktu dan pelayanan. Untuk itu peneliti menawarkan konsep Senyum, Salam dan Sapa. Ketika konsumen datang sudah ada staff yang bertugas untuk menyambut di depan menyambut dengan senyum tulus dengan diiringi mengucapkan salam dan selamat datang lalu mengantarkan konsumen ke tempat duduknya. Setelah itu staff lain datang untuk memberikan daftar menu. Ketika konsumen selesai makan dan hendak meninggalkan Waroeng Steak and Shake, maka staff bagian depan menyambut dengan menyapa mengucapkan terimakasih ditunggu kehadirannya kembali sambil tersenyum. Untuk ketepatan waktu pihak manajemen sudah berusaha mengatasinya dengan menambah jumlah karyawan.

\section{PUSTAKA ACUAN}

Anwar, Rosihon, Akhlak Tasawuf, Bandung: Pustaka Setia, 2010

Fattah, Nanang, Landasan Manajemen Pendidikan, Bandung: Remaja Rosdakarya,2001 Muslich. Etika Bisnis Islam.Cet I Jakarta: Ekonisia, 2004

Novita, Windya, Mendulang Rizki dengan Bisnis Syar'i, Jakarta: PT Gramedia

Siswanto, Pengantar Manajemen, Jakarta: Bumi Aksara, 2005

Sutarno, Serba-serbi Manajemen Bisnis,Yogyakarta: Graha IImu, 2012

Syukur, Suparman, Etika Religius, Yogyakarta : Pustaka Pelajar, 2004

Tanjung, Hendri dan Didin Hafidhuddin, Manajemen Syariah, Jakarta: Gema Insani Press, 2003

Tim Penyusun MKD IAIN Sunan Ampel Surabaya, Akhlak Tasawuf, Surabaya: IAIN SA Press, 2011

Wijayanti, Irene Diana Sari, Manajemen, Jogjakarta: Mitra Cendekia Press 